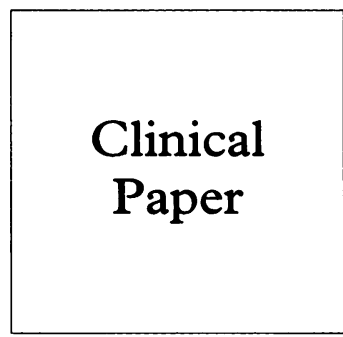

\title{
Occurrence of human papillomavirus types 16 and 18 in benign prostatic hyperplasia tissues of Saudi patients
}

\author{
M N Al-Ahdal, A H Kardar, A M Selim, G Kessie
}

Department of

Biological and Medical Research (MBC-03)

$M$ N Al-Ahdal

A M Selim

G Kessie

\section{Department of}

Pathology and

Laboratory Medicine

M N Al-Ahdal

Department of Surgery, King Faisal Specialist Hospital and Research Centre, PO Box 3354, Riyadh 11211, Saudi Arabia A H Kardar

Address correspondence to: Dr M N Al-Ahdal (at MBC-03).

Accepted for publication 7 August 1996

\begin{abstract}
Human papillomavirus, type 16 (HPV-16) and type 18 (HPV-18) are known to play a role in the development of neoplastic disorders of the urogenital organs. The presence of HPV-16 and HPV-18 in prostatic tissue with benign hyperplasia has been a matter of controversy. Some investigators have reported a high prevalence of HPV-16 DNA and a low prevalence of HPV-18 DNA in prostatic tissue, ${ }^{1-3}$ while others have failed to demonstrate either. ${ }^{4-6}$ In this study, we examined prostatic tissues of 19 cases of benign prostatic hyperplasia (BPH) from Saudi patients seen at our tertiary care medical centre to investigate the occurrence of both HPV-16 and HPV-18 DNAs by using the polymerase chain reaction (PCR), followed by Southern blot hybridisation (SBH) with type-specific probes. We also obtained void urine samples from the same patients to exclude those who show HPV-16 or HPV-18 positivity by PCR in order to ensure that the HPV DNA (if any) is in the prostatic tissue, and is not due to urethral contamination. Thirteen of the 19 patient specimens were found to be negative for HPV-16 and HPV-18 in their void urine, and their prostatic tissues were processed for HPV-16 and HPV-18 DNA detection. The chief symptoms of these patients were those of bladder outflow obstruction. Some of them developed urinary retention. Their age ranges between 61 and 80 years $($ mean $=70 \cdot 5)$. Standard methods were used for DNA extraction from prostatic tissue and for the subsequent PCR and SBH.
\end{abstract}

A

$\begin{array}{lllllllllllll}\text { P1P2 N1N2 } & 2 & 3 & 4 & 5 & 6 & 7 & 8 & 9 & 10 & 11 & 12 & 13\end{array}$

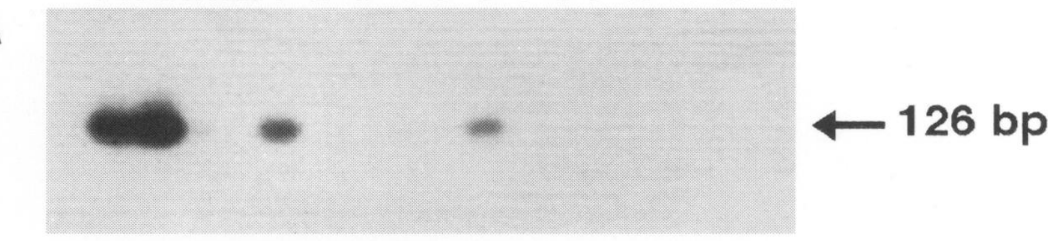

P1P2 N1N2 $12 \begin{array}{lllllllllllll} & 3 & 4 & 5 & 6 & 7 & 8 & 9 & 10 & 11 & 12 & 13\end{array}$

B

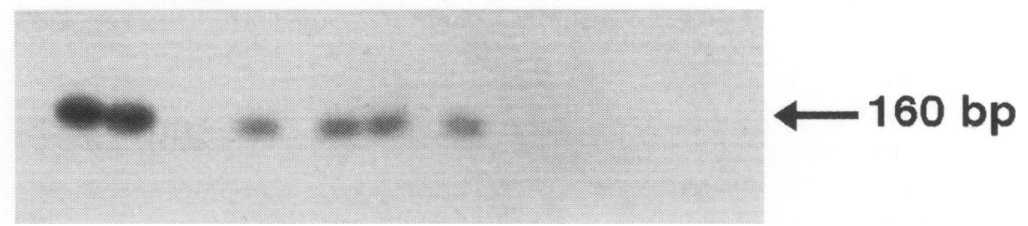

Southern blot hybridisation profile of PCR-amplified products from the E6 sequences of $H P V-16(A)$ and $H P V-18(B) . P 1$ and $P 2$ are positive controls of plasmid-cloned HPV DNA sequences and CaSki cellular DNA for HPV-16 or HeLa cellular DNA for HPV-

18 , respectively. N1 and N2 are negative controls of K562 cellular DNA and reagent control, respectively. Patient samples are in lanes 1-13. The sizes of PCR products are shown by arrows on the right.

Primers designed to amplify part of the E6 ORF were used as described by McNicol and Dodd. $^{3}$ The E6 gene was chosen for PCR amplification since it is preferentially conserved and is associated with cellular transformation. HPV-16 and HPV-18 DNAs cloned separately in pBR 322 plasmid (pHPVs) were kindly provided by $\mathrm{Dr}$ E-M de Villiers (Heidelberg, Germany) and were used as probes in SBH.

After PCR amplification, only two of the 13 $\mathrm{BPH}$ tissue specimens (specimens 1 and 6) gave positive signals in $\mathrm{SBH}$ using a radiolabelled probe specific for HPV-16 (fig, A). Both were a co-infection with HPV-18. For HPV-18, four specimens (1, 3, 4, and 6) showed positive signals in SBH using a radiolabelled probe specific for HPV-18 (fig, B), two of which were a co-infection with HPV-16 (specimens 1 and 6).

Our data indicate that in BPH from Saudi patients there is an occurrence rate of $15.4 \%$ for each of HPV-18 (2/13) and of both HPV16 and HPV-18 in the same specimen (2/13). HPV-16 alone was not detected. McNicol and Dodd $^{3}$ demonstrated a high prevalence of HPV-16 in BPH tissues (31/56, 55.4\%), low occurrence of HPV-16 and HPV-18 together $(3 / 56,5.4 \%)$, and no HPV-18 alone was detected. Except for the 7 specimens which they obtained by suprapubic prostatectomy where 6 were positive for HPV-16 only and 1 for both HPV-16 and HPV-18, the rest of the specimens were obtained by transurethral resection without examination of HPVs in patients' urethral epithelium, which may account for the reported high prevalence of HPV-16. In an earlier study by the same investigators, ${ }^{2}$ it was reported that HPV-16 was found in 14 of $15 \mathrm{BPH}$ cases (93.3\%). Their results are in general agreement with those of Rotola et $a l l^{7}$ who found HPV-16 in 14 of 17 BPH cases $(82 \%)$. On the other hand, some investigators have reported their negative findings. In a study by Ibrahim et $a l^{8}$ a total of 10 $\mathrm{BPH}$ samples were proven negative for HPV by PCR and in situ hybridisation. Serfling et $a l,{ }^{6}$ were not able to detect HPVs in a variety of prostatic conditions. Our finding that HPV18 was detected in more samples than HPV16 is unique. Most studies reported rare or no detection of HPV-18 alone. In the report of $\mathrm{McNicol}$ and Dodd, ${ }^{2} 3$ of the $15 \mathrm{BPH}$ cases were positive for HPV-18 and HPV-16, while in our study we identified 4 cases out of 13 positive for HPV-18. We cannot explain the reason for the existence of more cases of HPV- 
18 in our population. However, it could be due to a geographical clustering of HPV genotypes.

The conflicting results among various reports may have arisen from the use of different primers or procedures such as annealing temperatures. ${ }^{9}$ Primers from the E6 region of the HPV genome is able to amplify episomal and integrated HPV DNA sequences, while those from the frequently used L1 region may not amplify integrated HPV DNA. ${ }^{6}$ In view of the clear variation in results from many studies, more investigations should be carried out before a possible conclusion that the prostate may be a potential reservoir for the sexual transmission of high risk HPVs can be made. The use of various primers and procedures, the geographical location, and community traditions are major factors to be taken into consideration when results are interpreted.

1 McNicol PJ, Dodd JG. Detection of papillomavirus DNA in human prostatic tissue by Southern blot analysis. Can $\mathcal{F}$ Microbiol 1990;36:359-62.
2 McNicol PJ, Dodd JG. Detection of human papillomavirus DNA in prostate gland tissue by using the polymerase chain reaction amplification assay. $\mathcal{f}$ Clin Microbiol 1990; 28:409-12.

3 McNicol PJ, Dodd JG. High prevalence of human papillomavirus in prostate tissues. $\mathcal{F}$ Urol 1991;145:850-3.

4 Masood S, Rhatigan RM, Powell S, Thompson J, Rodenroth N. Human papillomavirus in prostatic cancer: no evidence found by in situ DNA hybridization. Southern Med $\mathcal{F}$ 1991;84:235-6.

5 Effert PJ, Fry RA, Neubauer A, Liu ET, Walther PJ. Human papillomavirus types 16 and 18 are not involved in human prostate carcinogenesis: analysis of archival human prostate cancer specimens by differential polymerase chain reaction. $f$ Urol 1992;147:192-6.

6 Serfling U, Ciancio G, Zhu W-Y, Leonardi C, Penneys NS. Human papillomavirus and herpes virus DNA are not detected in benign and malignant prostatic tissue using the polymerase chain reaction. F Urol 1992;148 using the

7 Rotola A, Monini P, Di Luca D, Savioli A, Simone R, Secchiero $\mathrm{P}$, et al. Presence and physical state of HPV DNA in prostate and urinary tract tissues. Int $\mathcal{f}$ Cancer 1992;52:359-65.

8 Ibrahim GK, Gravitt PE, Dittrich KL, Ibrahim SN, Melhus O, Anderson SM, et al. Detection of human papillomavirus in the prostate by polymerase chain reaction and in situ hybridization. $\mathcal{F}$ Urol 1992;148: 1822-6.

9 Sinclair AL, Nouri AME, Oliver RTD, Sexton C, Dalgleish AG. Bladder and prostate cancer screening for human papillomavirus by polymerase chain reaction: conflicting papillomavirus by polymerase chain reaction: conflicting
results using different annealing temperatures. $\mathrm{Br} \mathcal{F}$ results using different an
Biomed Sci 1993;50:350-4. 